\title{
Ueber die Jupitersnähe des Cometen 1884 Wolf im Jahre 1875.
}

Nach der von Laplace in der Mécanique céleste (Livre IX chap. II) ausgeführten Methode, welche bekanntlich von Burckhardt auf den L.exell'schen Cometen angewendet worden ist, versuchte ich mit Zugrundelegung der von Prof. Krueger in A. N. Nr. 2629 mitgetheilten Elemente die Bewegung des Wolf'schen Cometen in seiner Jupitersnähe im Jahre $1875 \mathrm{zu}$ berechnen. Diese Bestimmung ist natülich noch eine sehr unsichere, erstens, weil die gegenwärtigen Elemente noch lange nicht genau genug bekannt sind, zweitens, weil die Störungen während der Zeit von 1875 bis jetzt nicht berücksichtigt wurden.

Die jovicentrische Bewegung des Cometen von 1875 März 15.966 bis August 3.000 wurde durch die folgenden hyperbolischen Elemente dargestellt:

$$
\begin{aligned}
& T={ }_{1} 875 \text { Mai } 24.983 \text { m. Z. Berlin. } \\
& \delta 8=292^{\circ} 5^{\circ} .0 \\
& i=66 \text { I } 8.8\} \text { I } 884.0 \\
& \left.\omega=3^{8} 40.9\right\} \\
& a=-0.024596 \\
& e=4.3104 \\
& q=0.081424
\end{aligned}
$$

Die Ablenkung, die der Comet durch die Jupitersanziehung erfahren hatte, beträgt etwa $26 \% 8$.

Berlin I 884 Nov. 23 .

$\mathrm{Zusatz}$ des Herausgebers. Es ist wohl kaum nöthig darauf aufmerksam zu machen, und der Verfasser hat dies selbst ausdrücklich hervorgehoben, dass die Grundlagen vorstehender Rechnung noch sehr unsicher sind. Indessen scheint es immerhin interessant zu erfahren, wie sich der Einfluss des Jupiter unter gewissen angenommenen Verhältnissen äussern kann.

\section{Todes-Anzeige.}

John Birmingham died at his residence Millbrook near Tuam Co. Galway on Sept. $7188_{4}$ in his $68^{\text {th }}$ year. $\mathrm{He}$ is considered to have been the first person in Europe at least to observe on May I 2 1866 the sudden blazing forth of the small star $T$ Coronae as a star of the second magnitude. The account of his observation is given in the Monthly Notices R. A. S. vol. XXVI.

His well known Catalogue of the Red Stars was laid before the Royal Irish Academy June $26 \quad$ I 876 and appeared in vol. XXVI of the Transactions of the Academy. He was engaged on a revision of this work at the time of his death. In preparing this catalogue he was led to the discovery of several variable stars.

He contributed papers on the geology of his neighbourhood to the Journal of the Geological Society of Ireland, the British Association Reports and the Natural History Review.

He was presented by the Royal Irish Academy on Jan. I 4 I884 with a Cunningham Gold Medal for his distinguished observations in Astronomy with special reference to his Catalogue of the Red Stars.

At the time of his death he was employed under the Commissioners of Public Works in Ireland as Local Inspector for conducting the enquiries arising on applications for loans under the Iaand Law (Ireland) Act.

Mr. Birmingham was a person of much general culture, kind and courteous in disposition, and his loss will be much felt amongst his friends and acquaintances.

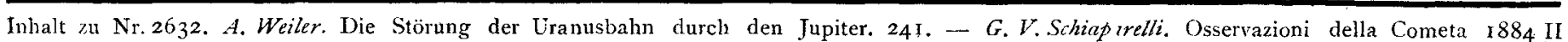
(Barnard). 253. - W. Winkler. Beobachtungen des Cometen I 884 Wolf. 253 . - R. Lehmann-Fühes. Ueber die Jupitersnähe des Cometen I 884 Wolf im Jahre 1875.255 . - Todes-Anzeige betr. John Birmingham 255.

Cieschlossen 1884 Dec. A. Herausgeber: A. Krueger. Jruck von C. F. Mohr. Expedition: Sternwarte in Kiel. 